\title{
New Frontiers: Training Forensic Accountants Within The Accounting Program
}

Vinita Ramaswamy, (E-mail: vinitar@stthom.edu), University of St. Thomas, Houston

\begin{abstract}
Accountants have recently been subject to very unpleasant publicity following the collapse of Enron and other major companies. There has been a plethora of accounting failures and accounting restatements of falsified earnings, with litigations and prosecutions taking place every day. As the FASB struggles to tighten the loopholes in accounting, and Congress and the SEC try to build safeguards for corporate governance, one group of accountants has been quietly helping corporations and investors alike in rebuilding confidence in financial statements. These are the forensic accountants. The forensic accountant actively looks for fraudulent transactions and misrepresentations. Such an accountant has a major role to play in this new environment, and universities have the responsibility to train future accountants to adequately meet the demands of the business world.
\end{abstract}

\section{RAPID CHANGES IN THE ACCOUNTING PROFESSION}

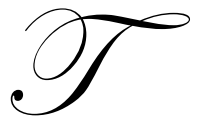

he landscape of business has changed dramatically, and has taken the accountants along at warp speed. First, the ability to automate many business functions has greatly streamlined operations in organizations across all industry lines, freeing accountants from the day-to -day tasks of debiting and crediting. Second, with the advent of the Internet, the accountants' financial statements have been sidelined by numerous reports provided by management, analysts, mutual funds and scores of other players on the World Wide Web. Third, as the demands of a global economy accelerate, the accountants have to deal with international markets, their accounting rules and currencies, as well with financial derivatives, divestitures, spinoffs, tracking stocks and the many deals that occur in the financial marketplace. The accountant has had to develop an entire new set of skills to deal with this changing environment.

And then came Enron! Worldcom! Global Crossing! Tyco! Xerox! Adelphia! These are just a few names on the Wall Street List of Infamy - companies that manipulated accounting rules to boost their earnings in a stock market gone wild. The year 2002 has gone down in the annals of accounting history as the Year Of Truth, when companies disclosed billions of dollars of financial fraud. The GAO reports that almost $10 \%$ of companies registered with the SEC issued earnings restatements between the years 1997 and 2002. The stock market went into a downward spiral as investors lost confidence in corporate governance and in the reported financial statements. The FASB and the SEC scrambled to find solutions to the problem of such ubiquitous financial fraud. Even the Congress stepped in with its Bill to regulate corporate accounting and managerial responsibility.

If such widespread fraud occurs with comparative infrequency in the long history of American accounting, let us get into the quieter waters of small business, banking, insurance, personal finance and vendor contracts. Fraud is as prevalent here in the day-to-day business as it seems to be in the corporate world. Some statistics quote a loss of \$ 900 billion annually from fraud and embezzlement. The average company loses \$9 per day due to theft and pilferage. Companies routinely find themselves in court these days for everything from vendor fraud to employee embezzlement. 
In this environment of fraud and suspicion, there is great demand - even a clamor for a new kind of accountant: the forensic accountant. Part Sherlock Holmes, part financial wizard, these accountants investigate and interpret financial statements and testify in court. The expert witness testimony of the forensic accountant has forced businesses to restructure, and millions of dollars to be paid in damages; people have on occasion even gone to jail. The practical and in-depth analysis that a forensic accountant brings to a case helps to uncover underlying problems in a business.

\section{A BRIEF HISTORY OF FORENSIC ACCOUNTING}

Forensic accountants have been around for nearly 200 years. The earliest reference was found in 1824 in an accountant's advertising circular in Glasgow, Scotland. These special accountants gave testimony in court and in arbitration proceedings. Interest in forensic accounting spread through the United States and England early in the twentieth century. One of the first institutions to use the services of such investigative accountants was the IRS. The story of Al Capone the famous mobster being caught on a tax evasion scheme is well-known. The FBI decided to use forensic accountants and employed nearly 500 such agents during World War II. As a profession, forensic accounting continued to grow during the latter half of the century, as GAAP and tax laws became widespread and mandatory.

The following are a few major milestones in forensic accounting:

- 1942: Maurice E. Peloubet published "Forensic Accounting: It’s place in today’s economy."

- 1982: Francis C. Dykman wrote "Forensic Accounting: The Accountant as an Expert Witness."

- 1986: The AICPA issued Practice Aid \# 7, outlining six areas of litigation services - damages, antitrust analysis, accounting, valuation, general consulting and analyses.

- $\quad$ 1988: Association of Certified Fraud Examiners established

- $\quad$ 1988: A new genre of detective novels where the forensic accountant was the star.

- $\quad$ 1992: The American College of Forensic Examiners was founded.

- $\quad$ 1997: The American Board of Forensic Accountants was founded

- 2000: The Journal of Forensic Accounting, Auditing, Fraud and Taxation was founded.

Forensic accounting is hardly a new field, but in recent years, banks, insurance companies and even police agencies have increased the use of these experts. A study conducted by Kessler International ( a forensic accounting and investigative firm) showed that there is a growing need for experienced forensic accountants. ABCnews.com reports that industry insiders expect more companies to use forensic accountants as preventative measures as the demand for trustworthy financial statements increases in the wake of the recent accounting scandals. Todd Avery, president of the risk consulting firm, Kroll Worldwide, says that many executives are paying greater attention to business controls and fraud prevention today than they were doing a few years ago. US News and World Report recently named "Forensic Accountant" as one of the most secure career tracks over the next few years - the profession made the "Twenty Hot Job Tracks" list.

Why is forensic accounting so popular now? According to some experts, this increased interest is because of the struggling stock market and lack of investor confidence which has forced many organizations to take a long, hard look at their financial statements. A sluggish economy with its attendant problems might also be an incentive to commit fraudulent acts, thus requiring the services of an expert. The increase in white collar crime and the difficulties faced by law enforcement agencies in uncovering fraud have also contributed to the growth of the profession. Many accounting firms believe that the market is sufficiently large to support an independent unit devoted strictly to forensic accounting. Whatever the reasoning may be, more and more forensic accountants are being called upon to use their investigative skills to seek out irregularities in their companies’ financial statements. 


\section{WHAT IS FORENSIC ACCOUNTING?}

Forensic accounting has been defined as "accounting analysis that can uncover possible fraud, that is suitable for presentation in court. Such analysis will from the basis for discussion, debate and dispute resolution." A forensic accountant uses his knowledge of accounting, law, investigative auditing and criminology to uncover fraud, find evidence and present such evidence in court if required to.

According to Dr. Larry Crumbley, a forensic accountant can be used in any of the following areas:

- $\quad$ Shareholder/partnership disputes

- $\quad$ Personal injury claims/accidents

- $\quad$ Business interruption/insurance claims

- $\quad$ Employee fraud

- $\quad$ Divorce/bankruptcy

- $\quad$ Professional negligence

- $\quad$ Financial statement fraud

- $\quad$ Retained by lawyers, law enforcement, banks and companies

Apart from knowledge of accounting, law and criminology, a forensic accountant also needs to be familiar with corporate financial planning and management. He also needs to have computer skills, good communication and interview skills.

\section{The Role Of The Auditor}

Fraud is no longer something that internal or external auditors can guard against with their periodic audits. A new category of accountants is needed to examine the books of a company specifically for fraud. The auditing profession has taken the position that it is not the responsibility of the external auditor to detect fraud. In its Statement of Auditing Standards (SAS), the AICPA states the following: "the ordinary examination directed to the expression of an opinion on financial statements is not primarily or specifically designed, and cannot be relied upon to disclose defalcations and other similar irregularities....(or) deliberate misrepresentation by management.” At the beginning of any assignment, however, the auditor should assess the possibility of material misstatements that could exist due to unintentional errors or fraudulent irregularities. Based on the initial assessment, the auditor should design an audit that provides reasonable assurance of detecting material errors and irregularities.

In response to current demand for greater corporate governance, the AICPA issued SAS 99 in 2002: Consideration of Fraud in a Financial Statement Audit. The new regulation encouraged auditors to:

- $\quad$ Discuss all possibilities of fraud that could take place within an organization so that an appropriate audit program could be designed

- $\quad$ Discuss with management and employees about the risk of fraud within the organization

- $\quad$ Design unpredictable fraud tests so that the surprise element could aid in uncovering fraud

- $\quad$ Pay special attention to any management override of the existing internal control system.

In "Forensic Accounting to the Forefront" by Wolosky, one of the investigative accountants talks about a significant difference between auditing and forensic accounting. The most important concern in auditing is materiality. However in investigative accounting, one small transaction that looks suspicious could be the thread that unravels a big accounting fraud.

An internal audit is the audit performed by an employee mainly to determine whether prescribed operating procedures are being followed. While doing this, many frauds can be discovered by internal auditors. But management has significant influence over an internal auditor's commitment to detect fraud. By limiting available resources or the scope of the audit, top management can effectively conceal fraud. Therefore, the external fraud auditor has a key role to play in uncovering fraud and presenting evidence. 
The terms "fraud examination" and "forensic accounting" are often used interchangeably, but they refer to different, but overlapping concepts. Forensic accounting is generally fraud examination done for litigation purposes.

\section{TEACHING FORENSIC ACCOUNTING}

Given the pervasiveness of fraud and the necessity of special skills in order to uncover such fraud, it becomes important to train forensic accountants - and colleges and universities have an important role to play. There are a number of universities and colleges offering a course in forensic accounting. Some universities, like the University of Toronto, offer a diploma in forensic accounting. The Association of Certified Fraud Examiners is actively encouraging universities to offer such courses by offering sample syllabi, videos and other material. Many universities report healthy enrolment in such classes.

Not all forensic accounting courses are taught in the same way. There are many approaches to teaching this very new course, some of which are as follows:

- $\quad$ A general course on all types of fraud perpetrated in all walks of life, including identity theft, telemarketing fraud, investment scams etc.

- $\quad$ A course specifically looking at fraud against organizations perpetrated by employees, vendors and customers

- $\quad$ A course specifically targeted at discovering financial statement fraud

- $\quad$ A fraud auditing and investigation course, looking at internal and external audit procedures

- $\quad$ A course dealing with gathering evidence of fraud, including testimonial, documentary, and surveillance evidence

- $\quad$ A course specifically targeted toward presenting evidence in court.

There is, of course, a lot of information overlap between these courses and their common focus is identifying and proving fraud. A sample syllabus for a general course in fraud would cover the following topics:

\section{Defining Fraud}

Albrecht (2003) defines fraud as a representation about a material fact which is false and intentionally or recklessly so, which is believed and acted upon by the victim, to the victim's damage. Fraud can be classified into these categories:

- $\quad$ Employee fraud: fraud committed by an employee against an organization

- Management fraud: fraud committed by management using financial statements to defraud stockholders, lenders and others who rely on those statements.

- Investment scams: fraud committed by individuals to trick their victims into investing their money in scams and false investments

- $\quad$ Vendor fraud: fraud committed by vendors by overcharging or falsely charging a company

- $\quad$ Customer fraud: fraud committed by customers that trick organizations into giving them something that they should not have.

- $\quad$ Identity theft: fraud committed by individuals who steal personal information from a victim and then go on to purchase goods or services using this information

- $\quad$ E-commerce fraud: fraud committed using the Internet and electronic transactions 


\section{Why Do People Commit Fraud?}

Like any other crime, fraud can be analyzed using the three elements of motive, means and opportunity.

- Motives: Why do people commit fraud? Fraud is usually committed to benefit oneself or benefit an organization. Personal reasons could include financial pressures, gambling or drugs, and work related pressures where an employee feels overworked and underpaid and unrecognized. For an organization, financial statement fraud is usually for obtaining cheap capital or for increasing stock value and therefore the value of stock options to management.

- $\quad$ Means: Like a smoking gun, fraud can be committed using computers, telephones, the Internet, annual reports, bank accounts, and things as simple as a cash register.

- $\quad$ Opportunity: Within an organization, lack of adequate internal controls provides a prime opportunity for fraud. Lack of audit trails and failure to punish the perpetrators also send signals encouraging fraud. In other cases, lack of access to important information, and ignorance and apathy can breed fraud.

\section{The Best Way To Control Fraud - Prevention}

Fraud, as we have said before, is extremely expensive, and the best way to minimize this fraud is to take measures to prevent fraud from occurring. This can be done in two ways:

- $\quad$ Creating the right environment in an organization by making the right hiring choices, and disseminating a well-understood code of conduct

- $\quad$ Eliminating opportunities for fraud by installing a good system of internal controls, with physical control of assets, proper authorizations, segregation of duties and proper documentation.

Such proactive fraud management can help the organization spot red flags and detect instances of fraud early. However, in spite of all good intentions, fraud does occur - and the forensic accountant is then called into the picture.

\section{Red Flags Of Fraud}

Fraud is not an openly visible crime. It can be detected only through "red flags" that indicate that ethics and honesty have been compromised within the company. Such red flags can be from the accounting system, lack of segregation of duties and other crucial internal control features, lack of integrity in top management behavior, unusual or extravagant behavior on part of employees, and numerous complaints or hotline tips. All these are indicators that fraud may exist - not necessarily proof of fraud.

\section{Fraud Investigation And Evidence}

The fraud investigation process begins with a predication - circumstances under which a reasonable, professionally trained expert could believe that fraud is taking place. Once there are such indications of fraud, the investigator develops a hypothesis and looks for evidence to prove the hypothesis. Such evidence can come from documents, interviews, observation and other physical clues like fingerprints. Based on the evidence acquired, the initial hypothesis can be proved or revised.

\section{Forensic Accountants In Court}

In court, the forensic accountant can be an expert witness, a consultant, or play other roles such as trier of fact, special master, court-appointed expert, referee, arbitrator, or mediator. A key piece of evidence is the report of the forensic accountant. The fraud report should not be accusatory nor conclusive as to guilt. It is critical to ensure that the tone of the report is not inflammatory or prejudicial. The fraud trial can be a civil or a criminal trial. In either case, the role of the forensic accountant is to study relevant materials documents, and the authoritative literature relating to the case on hand. Direct and cross examination questions will be asked, and the forensic accountant has the responsibility to answer these questions clearly and concisely. 
Other topics covered in a forensic accountant's class can include a detailed analysis of evidentiary types, embezzlement and other internal frauds, money laundering and external frauds, computer evidence and cybercriminals.

\section{TEXTBOOKS AVAILABLE}

While forensic accounting is fairly new in the academic area, there are a variety of books available. Some of the books are comprehensive, while others deal with specific topics. Here are some of the books available (topics covered by the books are in italics):

- $\quad$ Fraud Examination by W. Steve Albrecht, Wiley - Comprehensive coverage of all types of fraud

- $\quad$ Forensic and Investigative Accounting by Larry Crumbley, $\mathrm{CCH}$ - Comprehensive coverage, with Instructor Manual and Test Bank

- $\quad$ Principles of Fraud Examination by Joseph Wells, Wiley - New textbook with comprehensive coverage of various fraud schemes.

- $\quad$ Forensic Accounting by Hopwood et. al., McGraw Hill - Comprehensive coverage, with Instructor Manual and Test Bank

- $\quad$ Fraud Auditing and Forensic Accounting by G.Jack Bologna and Robert J. Lindquist, Wiley - Fraud against organizations, mainly by employees and vendors

- $\quad$ Business Fraud: Know It and Prevent It by James Blanco, Humanomics Publishing - Fraud against businesses

- $\quad$ Occupational Fraud and Abuse by Joseph T. Wells, Obsidian Publishing - Asset Misappropriation and Financial Statement Fraud

- $\quad$ Fraud 101: Techniques and Strategies by Howard Davia, Wiley - General coverage of all types of fraud

- $\quad$ Financial Investigation and Forensic Accounting by George Manning, CRC Press - Fraud auditing and investigative techniques within an organization

Other similar books are also available, although many of them are not set up as text books with end of the chapter questions and cases.

\section{USEFUL WEBSITES}

A search on key words like "Forensic Accounting”, "Fraud Examination”, "Fraud Investigation”, "Fraud Auditing" and other similar terms yield a number of websites with useful information, articles and investigative techniques. Here is a sampling of some of the most relevant websites:

- The official website of the Association of Certified Fraud Examiners provides a wealth of information about fraud resources and links to other websites

- $\quad$ The official website of the American College of Forensic Examiners : acfe.com - provides information about forensic accounting

- $\quad$ www.forensicaccounting.com has a comprehensive definition of forensic accounting and the work involved during forensic accounting engagements

- $\quad$ bus.lsu.edu/accounting/faculty/lcrumbley/forensic.html - website of Dr. Larry Crumbley, one of the pioneers in forensic accounting

- $\quad$ myacademiconlyhomepage.com/Accounting_Forensic.html - provides links to many forensic websites

- $\quad$ aicpa.org/antifraud - the AICPA's website dealing with fraud, especially financial statement fraud

- $\quad$ fraud.org, ckfraud.org, crimesandclues.com - websites that provide information about the various types of frauds and investigative techniques. 


\section{ADDING A FEW “EXTRAS” TO THE COURSE:}

The term "forensic" conjures up images of exciting discoveries and crime detection especially after the numerous TV shows based on the subject. In real life, forensic accounting is a patient examination of boxes of documents and computer files, careful interviews and study of statements, and a slow build up of evidence, piece by piece. While real life takes up a lot of leg work, forensic accounting classes can be turned into something more exciting, involving students as more than passive listeners. Here are some of the ideas that have been used in classes:

- $\quad$ Setting up "mock trials" at the end of class where students present evidence and "try" a case in forensic accounting

- $\quad$ Reading novels in forensic accounting - Dr. Larry Crumbley has written more than a dozen novels involving intrepid forensic accounting detectives

- $\quad$ Role playing, taking on the perspectives of management, the auditor, the fraud perpetrator and the forensic accountant

- $\quad$ Writing a short story involving fraud and presenting it in class.

- $\quad$ Trying out different interview techniques on each other/watching TV interviews and analyzing them

- $\quad$ Handwriting analysis/analysis of questioned documents

- Watching videos - the Association of Certified Fraud Examiners has a number of really good videos to purchase

- $\quad$ Guest speakers from accounting firms, the FBI, IRS and other agencies that investigate crime

Litigation support and the intricacies of deposition testimony, direct testimony and cross examination during trials are important to any course in forensic accounting and getting in guest speakers who have experience in these areas adds enormous value.

\section{QUALITIES AND QUALIFICATIONS OF A FORENSIC ACCOUNTANT}

A forensic accountant must be part detective and part accountant while analyzing, investigating, testing and examining evidence in order to present expert testimony on the occurrence of fraud. This requires knowledge of financial and managerial accounting, corporate financial management, advanced computer skills, a good knowledge of the legal environment, and strong communication skills. A naturally suspicious state of mind also helps the forensic accounting during the task of uncovering fraud. Crumbley et. al. (2003) outline a number of courses and knowledge content areas that would be necessary for a comprehensive program in Forensic Accounting:

- $\quad$ Basic foundational courses in Accounting and Finance for a solid understanding of financial statements and the markets in which they operate

- $\quad$ Financial Statement Analysis - for the ability to critically analyze financial statements and their related ratios

- $\quad$ Taxation and Business Law - for a thorough understanding of the legal elements of fraud

- $\quad$ Securities Law and Corporate Governance - for an indepth coverage of the specific regulations affecting companies and their behavior

- Information Systems - covering computer essentials and the flow of funds and information through the electronic media

- $\quad$ Business Valuation - the often complex methods of finding hidden assets and the correct value of a business are useful tools for the forensic accountant

- $\quad$ Criminology - for the many aspects of criminal law and procedure

- $\quad$ Psychology - for an understanding of human behavior that leads to fraud

- $\quad$ Business ethics - general ethics and specific codes that cover many professionals working in the field of finance and accounting

- $\quad$ Business Communication - for clear report writing and oral communication skills that are crucial for conducting interviews and expert testimony in court. 


\section{HOW DOES ONE BECOME A FORENSIC ACCOUNTANT?}

- $\quad$ One of the most popular certifications available is the CFE or the Certified Fraud Examiner. This is an examination offered by the Association of Certified Fraud Examiners. It consists of four parts: financial transactions, investigation, legal elements, and criminology.

- $\quad$ The American College of Forensic Examiners offers the "Certified Forensic Accountant” or the CrFA. This program qualifies the accountant in the areas of Fraud and Expert Testimony.

- $\quad$ The Certified Insolvency and Reorganization Accountant (CIRA) qualifies an accountant in the areas of insolvency and reorganizational accounting.

- $\quad$ The Association of Certified Fraud Specialists offers the Certified Fraud Specialist Certification

- $\quad$ Other resources include the Forensic Accounting Society of North America, the National Association of Certified Valuation Analysts and National Litigation Support Services Association.

\section{CONCLUSION}

Forensic accountants are currently in great demand, with the public need for honesty, fairness and transparency in reporting increasing exponentially. These forensic accountants need accounting, finance, law, investigative and research skills to identify, interpret, communicate and prevent fraud. As more and more companies look for forensic accountants, and professional organizations offer certifications in the area, it is becoming evident that the forensic accountant has a skill set that is very different from an auditor or a financial accountant. Universities must therefore be prepared to train such accountants to meet future needs of the profession.

\section{REFERENCES}

1. ABCnews.com, Forensic Accounting is a Hot Job April 2002

2. American Institute of Certified Public Accountants, SAS 99: Considerations of Fraud in a Financial Statement Audit, 2002

3. Association of Certified Fraud Examiners, www.acfe.com

4. Association of Certified Fraud Examiners, Report to the Nation on Occupational Fraud and Abuse, www.acfe.com, 2006

5. $\quad$ Financial Restatements, General Accounting Office Report, 2002

6. Forensic and Investigative Accounting by Crumbley, Heitger, Smith; CCH Publishing, 2003

7. $\quad$ Fraud Examination, by Albrecht, W. S., Publisher: Thomson SouthWestern

8. Kessler International Study Revealed That Forensic Accountants Needed as Economy Worsens. Press release, 2002

9. USA Today, Twenty Hot Job Tracks, 2002 Survey

10. Wolosky, H.W., Forensic Accountants to the Forefront, WebCPA, February 2004 